\title{
$\$$ Research Square

\section{Impact of invasive species on the density and body size of an insular endemic lizard (Trachylepis atlantica)}

\section{Vinícius Peron de Oliveira Gasparotto}

Universidade de Sao Paulo

\section{Tatiane Micheletti}

Brazilian Institute for Conservation Medicine

Paulo Rogério Mangini

Brazilian Institute for Conservation Medicine

Ricardo Augusto Dias ( $\nabla$ dias@vps.fmvz.usp.br)

Universidade de Sao Paulo https://orcid.org/0000-0002-8241-7699

Research article

Keywords: Fernando de Noronha, Scincidae, Skink, Brazil, Conservation.

Posted Date: November 8th, 2019

DOl: https://doi.org/10.21203/rs.2.17079/v1

License: (c) (i) This work is licensed under a Creative Commons Attribution 4.0 International License.

Read Full License 


\section{Abstract}

Backgroundlnvasive species have been responsible for the extinction of several species around the world. The Noronha skink is an endemic lizard from the Fernando de Noronha archipelago, Brazil, that has been suffering from habitat changes and the introduction of invasive species. ResultsTwo methods were used to estimate the density of the Noronha skink. The density on the main island was $0.167 \pm 0.090$ individuals $/ \mathrm{m}^{2}$; that on the secondary islands was $0.357 \pm 0.170$ individuals $/ \mathrm{m}^{2}$; and that on the entire archipelago was $0.184 \pm 0.109$ individuals $/ \mathrm{m}^{2}$. Moreover, the morphometric parameters of the Noronha skink were compared between the main island and secondary islands. The values of all parameters were higher on the secondary islands. ConclusionThe occurrence of invasive species on the main island seems to be a determining factor in the density and body size of the Noronha skink.

\section{Background}

Due to their geographic isolation, oceanic islands show unique colonization dynamics, with elevated endemism and low species richness, which increase the population density of species in these environments $[1,2,3]$. However, oceanic islands have been losing their fauna, including their endemic species, since the fifteenth century due to human colonization $[4,5]$.

Anthropic activities such as urbanization, pollution, habitat fragmentation, and introduction of invasive species are proven threats to the environment and biodiversity globally [6,7]. These threats are also responsible for the extinction and decline of species on the Fernando de Noronha archipelago [8], an oceanic archipelago located northeast of Brazil; the affected species include the Noronha rat (Noronhomys vespuccii) [9] and the Noronha skink (Trachylepis atlantica) [10].

The Noronha skink (Figure 1) is one of the oldest residents of the Fernando de Noronha archipelago, since radiation from its African ancestors occurred during the Miocene (10-27 million years ago) [11]. This is the lizard species located farthest east from South America [12] and is the only species of the genus Trachylepis in the New World.

This lizard is charismatic and fearless towards humans due to its evolution and speciation in a predatorfree environment and shows important ecological functions associated with the equilibrium of the archipelago ecosystem. One of these functions is the pollination of plants such as mulungu (Erythrina velutina) when the skink visits its flowers searching for nectar [13].

Although a reduction in the abundance of $T$. atlantica can be easily visualized on the archipelago, it is now also being reported by local inhabitants. Considering that the skink is endemic to Fernando de Noronha in an area smaller than $30 \mathrm{~km}^{2}$, in 2017, this species was designated as threatened by the State of Pernambuco, which administers the archipelago [10].

The present work aimed to determine the density and morphometry of this species in different landscapes of the archipelago and to associate these findings with the human presence, anthropic 
activities and threats caused by invasive species. As of the time of writing, this study was the first to examine the density and perform morphometric comparisons of $T$. atlantica between the islands of the archipelago.

\section{Results}

\section{Density and abundance}

The capture and recapture method was performed in six parcels in different landscapes of the main island of the archipelago of Fernando de Noronha. The results are shown in Table 1.

Table 1. Population density of Trachylepis atlantica in four different landscapes of the main island of the Fernando de Noronha archipelago.

\begin{tabular}{lcccccccc}
\hline Landscape & Date & $\begin{array}{c}\text { Population } \\
\text { estimate }\end{array}$ & $\begin{array}{c}\text { Standard } \\
\text { error }\end{array}$ & $\begin{array}{c}\text { Lower } \\
\text { CI }\end{array}$ & $\begin{array}{c}\text { Upper } \\
\text { CI }\end{array}$ & $\begin{array}{c}\text { Effort } \\
\text { (min) }\end{array}$ & $\begin{array}{c}\text { Area } \\
(\mathrm{m} \text { ) }\end{array}$ & $\begin{array}{c}\text { Density } \\
\text { (ind./m!) }\end{array}$ \\
\hline Quarry & February/2016 & 22.09 & 3.73 & 15.91 & 30.68 & 97 & 13.5 & 1.64 \\
\hline Shrub & February/2015 & 59.70 & 6.86 & 47.70 & 74.73 & 157 & 36.7 & 1.63 \\
\hline Urbanized & February/2016 & 10.86 & 2.21 & 7.33 & 16.11 & 61 & 7.7 & 1.41 \\
\hline Shrub & November/2016 & 13.21 & 2.03 & 9.80 & 17.82 & 106 & 30 & 0.44 \\
\hline Shrub & October/2016 & 12.29 & 2.46 & 8.34 & 18.11 & 96 & 48 & 0.26 \\
\hline Forest & October/2016 & 11.51 & 2.06 & 8.13 & 16.30 & 96 & 52 & 0.22 \\
\hline
\end{tabular}

A total of 488 individuals were counted at 150 sampling points, including 113 (75.3\%) on the main island, 19 (12.6\%) on Rata Island, $16(10.7 \%)$ on Meio Island, 1 (0.7\%) on Chapeu Island, and $1(0.7 \%)$ on Morro da Viuvinha Island. The counts varied from 0 to 19 individuals and the density in the sampling areas from 0 to 1.51 individuals $/ \mathrm{m}^{2}$.

T. atlantica density was estimated to be $0.167 \pm 0.090$ individuals $/ \mathrm{m}^{2}$ on the main island, $0.357 \pm 0.170$ individuals $/ \mathrm{m}^{2}$ on the secondary islands (Rata, Meio, Chapeu, and Morro da Viuvinha), and $0.184 \pm 0.109$ individuals $/ \mathrm{m}^{2}$ across the entire archipelago of Fernando de Noronha. The resulting density map, along with the sampling points and parcels, is shown in Figure 2.

The abundance of $T$. atlantica was estimated to be $3,295,440$ individuals considering the tridimensional area of the archipelago of Fernando de Noronha, including 2,820,630 individuals on the main island and 474,810 individuals on the secondary islands. The metadata of the interpolation map were generated 
with QGIS software, and the total area of the archipelago was $18.22 \mathrm{~km}^{2}$ (main island, $16.89 \mathrm{~km}^{2}$, and secondary islands, $1.33 \mathrm{~km}^{2}$ ).

\section{Morphometric evaluation}

Among the 135 individuals captured between 2014 and 2016, 114 (84.4\%) were from the main island, and 21 (15.5\%) were from the secondary islands (10 from Rata Island, 7 from Meio Island, 2 from Sao Jose Island, and 2 from Chapeu Island). All morphometric parameters showed greater values on the secondary islands. Males from the secondary islands were larger and heavier than males from the main island (Table 2). Moreover, males were heavier and larger than females on both the main island and the secondary islands (Table 3).

Table 2. Mean values and differences in morphometric parameters of males and females of Trachylepis atlantica among the species captured on the main island and secondary islands of the Fernando de Noronha archipelago. 


\begin{tabular}{|c|c|c|c|c|c|}
\hline Parameter & Sex & Island & Mean & $\begin{array}{l}\text { Mean difference } \\
\text { (CI 95\%) }\end{array}$ & $\mathrm{p}$ \\
\hline \multirow{4}{*}{$\begin{array}{l}\text { Head length } \\
(\mathrm{CCab})(\mathrm{cm})\end{array}$} & \multirow[t]{2}{*}{ Female $^{b}$} & Main & 1.44 & \multirow{2}{*}{$\begin{array}{c}-0.07 \\
(-0.40 ; 0.26)\end{array}$} & \multirow[t]{2}{*}{0.671} \\
\hline & & Secondary & 1.51 & & \\
\hline & \multirow[t]{2}{*}{ Male $^{\mathrm{a}}$} & Main & 1.76 & \multirow{2}{*}{$\begin{array}{c}-0.30 \\
(-0.46 ;-0.14)\end{array}$} & \multirow[t]{2}{*}{$<0.001$} \\
\hline & & Secondary & 2.06 & & \\
\hline \multirow{4}{*}{$\begin{array}{l}\text { Rostrum-cloaca length } \\
(\mathrm{CRC})(\mathrm{cm})\end{array}$} & \multirow{2}{*}{ Female $^{\mathrm{b}}$} & Main & 7.93 & \multirow{2}{*}{$\begin{array}{c}-0.58 \\
(-2.18 ; 1.02)\end{array}$} & \multirow[t]{2}{*}{0.469} \\
\hline & & Secondary & 8.51 & & \\
\hline & \multirow[t]{2}{*}{ Male $^{\mathrm{a}}$} & Main & 9.40 & \multirow{2}{*}{$\begin{array}{c}-0.70 \\
(-1.34 ;-0.06)\end{array}$} & \multirow[t]{2}{*}{0.032} \\
\hline & & Secondary & 10.10 & & \\
\hline \multirow{4}{*}{$\begin{array}{l}\text { Tail length } \\
(\mathrm{CCau})(\mathrm{cm})^{\mathrm{C}}\end{array}$} & \multirow[t]{2}{*}{ Female $^{b}$} & Main & 11.88 & \multirow{2}{*}{$\begin{array}{c}-0.53 \\
(-3.80 ; 2.73)\end{array}$} & \multirow[t]{2}{*}{0.743} \\
\hline & & Secondary & 12.42 & & \\
\hline & \multirow[t]{2}{*}{ Male b } & Main & 14.27 & \multirow{2}{*}{$\begin{array}{c}-1.52 \\
(-3.43 ; 0.38)\end{array}$} & \multirow[t]{2}{*}{0.115} \\
\hline & & Secondary & 15.79 & & \\
\hline \multirow{4}{*}{$\begin{array}{l}\text { Total length } \\
(\text { CTot })(\mathrm{cm})^{\mathrm{c}}\end{array}$} & \multirow[t]{2}{*}{ Female $^{b}$} & Main & 19.69 & \multirow{2}{*}{$\begin{array}{c}-1.24 \\
(-6.19 ; 3.71)\end{array}$} & \multirow[t]{2}{*}{0.058} \\
\hline & & Secondary & 20.93 & & \\
\hline & \multirow[t]{2}{*}{ Male $^{\mathrm{a}}$} & Main & 23.42 & \multirow{2}{*}{$\begin{array}{c}-2.29 \\
(-4.43 ;-0.15)\end{array}$} & \multirow[t]{2}{*}{0.036} \\
\hline & & Secondary & 25.71 & & \\
\hline \multirow{4}{*}{$\begin{array}{l}\text { Weight } \\
(\mathrm{g})^{\mathrm{c}}\end{array}$} & \multirow[t]{2}{*}{ Female b } & Main & 12.46 & \multirow{2}{*}{$\begin{array}{c}-1.21 \\
(-3.89 ; 1.49)\end{array}$} & \multirow[t]{2}{*}{0.370} \\
\hline & & Secondary & 13.67 & & \\
\hline & \multirow[t]{2}{*}{ Male $^{\mathrm{a}}$} & Main & 18.21 & -7.34 & \multirow[t]{2}{*}{0.002} \\
\hline & & Secondary & 25.56 & $(-11.79 ;-2.90)$ & \\
\hline
\end{tabular}

Table 3. Mean values and differences in morphometric parameters between males and females of Trachylepis atlantica captured on the main island and secondary islands of the Fernando de Noronha archipelago. 


\begin{tabular}{|c|c|c|c|c|c|}
\hline Parameter & Island & Sex & Mean & $\begin{array}{l}\text { Mean difference } \\
\text { (CI 95\%) }\end{array}$ & $\mathrm{p}$ \\
\hline \multirow{4}{*}{$\begin{array}{l}\text { Head length } \\
(\mathrm{CCab})(\mathrm{cm})^{\mathrm{a}}\end{array}$} & \multirow[t]{2}{*}{ Main } & Female & 1.53 & \multirow{2}{*}{$\begin{array}{c}-0.23 \\
(-0.34 ;-0.12)\end{array}$} & \multirow[t]{2}{*}{$<0.001$} \\
\hline & & Male & 1.76 & & \\
\hline & \multirow[t]{2}{*}{ Secondary } & Female & 1.68 & \multirow{2}{*}{$\begin{array}{c}-0.55 \\
(-0.71 ;-0.38)\end{array}$} & \multirow[t]{2}{*}{$<0.001$} \\
\hline & & Male & 1.87 & & \\
\hline \multirow{4}{*}{$\begin{array}{l}\text { Rostrum-cloaca } \\
(\mathrm{CRC})(\mathrm{cm})^{\mathrm{a}}\end{array}$} & \multirow[t]{2}{*}{ Main } & Female & 8.40 & \multirow{2}{*}{$\begin{array}{c}-1.02 \\
(-1.43 ;-0.61)\end{array}$} & \multirow[t]{2}{*}{$<0.001$} \\
\hline & & Male & 9.42 & & \\
\hline & \multirow[t]{2}{*}{ Secondary } & Female & 9.06 & \multirow{2}{*}{$\begin{array}{c}-1.59 \\
(-2.42 ;-0.75)\end{array}$} & \multirow[t]{2}{*}{0.001} \\
\hline & & Male & 9.54 & & \\
\hline \multirow{4}{*}{$\begin{array}{l}\text { Tail length } \\
(\mathrm{CCau})(\mathrm{cm})^{\mathrm{a}, \mathrm{c}}\end{array}$} & \multirow[t]{2}{*}{ Main } & Female & 12.40 & \multirow{2}{*}{$\begin{array}{c}-1.81 \\
(-2.76 ;-0.87)\end{array}$} & \multirow[t]{2}{*}{$<0.001$} \\
\hline & & Male & 14.21 & & \\
\hline & \multirow[t]{2}{*}{ Secondary } & Female & 13.58 & \multirow{2}{*}{$\begin{array}{c}-3.37 \\
(-5.12 ;-1.61)\end{array}$} & \multirow[t]{2}{*}{0.001} \\
\hline & & Male & 14.44 & & \\
\hline \multirow{4}{*}{ 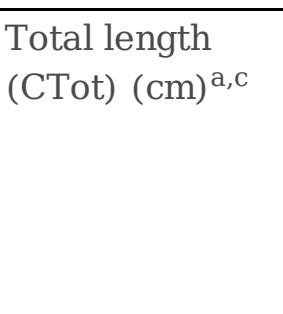 } & \multirow[t]{2}{*}{ Main } & Female & 20.80 & \multirow{2}{*}{$\begin{array}{c}-2.61 \\
(-3.84 ;-1.38)\end{array}$} & \multirow[t]{2}{*}{$<0.001$} \\
\hline & & Male & 23.41 & & \\
\hline & \multirow[t]{2}{*}{ Secondary } & Female & 22.50 & \multirow{2}{*}{$\begin{array}{c}-4.95 \\
(-7.00 ;-2.90)\end{array}$} & \multirow[t]{2}{*}{$<0.001$} \\
\hline & & Male & 23.99 & & \\
\hline \multirow{4}{*}{$\begin{array}{l}\text { Weight } \\
(g)^{a, c}\end{array}$} & \multirow[t]{2}{*}{ Main } & Female & 12.45 & \multirow{2}{*}{$\begin{array}{c}-6.62 \\
(-8.94 ;-4.31)\end{array}$} & \multirow[t]{2}{*}{$<0.001$} \\
\hline & & Male & 19.08 & & \\
\hline & \multirow[t]{2}{*}{ Secondary } & Female & 16.60 & \multirow{2}{*}{$\begin{array}{c}-12.57 \\
(-16.83 ;-8.32)\end{array}$} & \multirow[t]{2}{*}{$<0.001$} \\
\hline & & Male & 21.11 & & \\
\hline
\end{tabular}

\section{Discussion}

The present study estimated the population density of $T$. atlantica in different landscapes of the archipelago of Fernando de Noronha, providing information that was previously nonexistent. Comparison of the results of the present study with similar studies of the genus Trachylepis on other islands demonstrated that the density of $T$. atlantica is greater than that of $T$. adamastor $\left(0.012\right.$ individuals $\left./ \mathrm{m}^{2}\right)$, endemic to Tinhosa Grande Island [14], and T. seychellensis ( 0.021 individuals $\left./ \mathrm{m}^{2}\right)$, endemic to the Seychelles Islands [15].

The increased density of $T$. atlantica in comparison with those of other Trachylepis species may be explained by the fact that Tinhosa Grande Island has a small size and no vegetation, offering few resources for $T$. adamastor. In contrast, the Seychelles Islands have a larger area than Fernando de 
Noronha but harbour numerous natural and invasive predators of $T$. seychellensis, such as snakes and birds of prey [16]. Both the Tinhosa Grande and Seychelles Islands exhibit unfavourable environments preventing their Trachylepis species from reaching the densities observed for $T$. atlantica.

The phenomenon known as density compensation [17] indicates the expected abundance of $T$. atlantica and why it is currently lower than expected. According to Buckley and Jetz [18], insular species tend to reach population densities above those of their continental conspecifics. An example of this phenomenon is provided by the tegu lizard (Salvator merianae), which presents densities of $6.9 * 10^{-4}$ individuals $/ \mathrm{m}^{2}$ in the main island of Fernando de Noronha [19] and $6.3 * 10^{-5}$ individuals $/ \mathrm{m}^{2}$ in continental Brazil (Espirito Santo State) [20], i.e., at least 10 times higher in insular environment.

The low native species richness of the Fernando de Noronha archipelago and the absence of natural predators prior to human occupation in the sixteenth century are probably the key factors in the high density of $T$. atlantica on the archipelago [21]. The lack of species sharing the same ecological niche as $T$. atlantica means that there is low interspecific competition, which, allied with the absence of natural predators, resulted in low predation rates during the early establishment of this species on the archipelago [21].

However, the actual population density of $T$. atlantica is not sufficient to maintain the species in the long term. If all the archipelago presented the same density found on the secondary islands, which are free of cats and exhibit low densities of tegu lizards [19], the abundance of the Noronha skink would be $6,504,540$ individuals. Thus, it can be inferred that the actual population of $T$. atlantica is at least $50.7 \%$ below the expected abundance.

The Fernando de Noronha archipelago exhibits rich diversity of exotic and invasive species such as rats (Rattus rattus and $R$. norvegicus), mice (Mus musculus), rock cavies (Kerodon rupestris), domestic dogs (Canis lupus familiaris), domestic cats (Felis silvestris catus), cattle egrets (Bubulcus ibis), tegu lizards (Salvator merianae), and rococo toads (Bufus jimi), especially on the main island [22]. Cats were probably introduced to the archipelago with the first landing of the European colonizers, during the sixteenth century [23]. These animals are superpredators in insular environments and are responsible for the extinction of birds, mammals and reptiles on several islands worldwide [24,25]. On the Fernando de Noronha archipelago, the number of cats is estimated to be approximately 1,300 individuals on the main island, which is considered one of the highest densities on islands worldwide [23].

Due to the evolution and speciation of the Noronha skink in the absence of natural predators, behavioural defences are also absent in this species, making it vulnerable in interspecific encounters. Cats, rats and cattle egrets are the main threats and prey upon $T$. atlantica individuals daily. Dias et al. [23] described the predation frequency of $T$. atlantica by cats reported by the resident inhabitants who maintain cats in their households with the aim of controlling the Noronha skink population.

The predation pressure generated by invasive species, especially cats, may directly influence the population densities of the $T$. atlantica recorded in the present study. This hypothesis is corroborated by 
Case and Bolger [26], who noted that cats are considered successful predators of small reptiles in several types of environments. Smith et al. [27] concluded that the predation of reptiles by invasive species on Christmas Island was the main factor of the decline of its native reptiles.

Through stable isotope analyses and analyses of prey fragments in faecal samples of cats and rats and the stomach contents of tegu lizards, Gaiotto [28] determined the potential trophic relations of producers and consumers on Fernando de Noronha. The results showed that T. atlantica corresponded to $18.8 \%$ of the cats' diet and $30.3 \%$ of the rats' diet [28].

No proven presence of cats, a proven low presence or absence of tegu lizards [19], and a high density of rodents [29] are reported for the secondary islands of the Fernando de Noronha archipelago. The absence of a single invasive species with a high predation potential, such as cats, may have allowed the higher density of $T$. atlantica on the secondary islands ( 0.357 individuals $\left./ \mathrm{m}^{2}\right)$, which was $119 \%$ higher than the density observed on the main island $\left(0.167\right.$ individuals $\left./ \mathrm{m}^{2}\right)$. Not only is the density higher, but the body size and mass of $T$. atlantica individuals are also significantly higher on the secondary islands than on the main island, despite the expected body size and mass of males being greater than those of females.

The greater body size and mass of $T$. atlantica on the secondary islands may also be related to longevity. Classic studies have shown that reptiles grow constantly during their lives and, according to Goss [30], amphibians and reptiles retain their cartilage epiphyses throughout their lives, allowing constant growth. These findings were corroborated by Andrews [31], who noted that even if growth is insignificant after reaching asymptotic size, reptiles grow throughout their lives.

According to Olsson and Shine [32], the constant growth of reptiles is best observed in some lizards with short longevity. This information corroborates the results of the present work. The secondary islands of the Fernando de Noronha archipelago have been subject to fewer anthropic interferences and harbour fewer invasive species, which may increase the longevity of $T$. atlantica compared to the individuals on the main island.

The effects of the insular conditions on body size are referred to as the "island rule" and may be associated with intrinsic (p.e., climate) or extrinsic (p.e., predation) factors [33,34,35]. According to Russell et al. [36], when islands exhibit the same biogeographic climatic conditions, extrinsic factors may not explain body size differences. However, the high predation rate of cats on the Noronha skink and competition with other invasive species have probably created selective pressure that determines the observed density and body size differences, resulting in population decline on the main island.

With the arrival of new invasive species in recent decades, such as the tegu lizard (Salvator merianae), which was introduced before 1950 [19], and the cattle egret (Bubulcus ibis), which arrived naturally in the 1990s [37], the increases in the mortality rates and population decline of $T$. atlantica are concerning. According to Gaiotto [28], 19.6\% of the tegu's diet is composed of T. atlantica. Silva-Jr et al. [38] also reported predation of cattle egrets upon $T$. atlantica. 


\section{Conclusions}

The morphometric comparisons showed that the longevity of $T$. atlantica on the main island is reduced compared to that of individuals on the secondary islands. The difference in the invasive species communities of the main and secondary islands is the most likely factor determining the density and morphometric parameter differences of $T$. atlantica. The results are robust to indicate the threats that this endemic species, $T$. atlantica, is subjected to, and these findings may contribute to mitigation actions and the inclusion of this species in the red list of IUCN.

\section{Methods}

\section{Study area}

The archipelago of Fernando de Noronha ( $\left.3^{\circ} 51^{\prime} 13.71^{\prime \prime} \mathrm{S}, 32^{\circ} 25^{\prime} 25.63^{\prime \prime} \mathrm{W}\right)$ is composed of 21 islands and islets with a total area of $18.2 \mathrm{~km}^{2}$ [22,23]. It is one of the four Brazilian oceanic insular sets, including the Archipelago of Sao Pedro and Sao Paulo, the Rocas Atol, Trindade and Martin Vaz Islands and the Archipelago of Fernando de Noronha.

The archipelago has a wet and dry tropical climate, with the rainy season occurring from March to July and the dry season from August to February [39]. Currently, the predominant vegetation of the archipelago is deciduous seasonal forest, similar to that in the Brazilian northeast [40]. On the south face of the archipelago, which is exposed to equatorial trade winds, the vegetation is arboreal with some patches where grass prevails [41].

Fernando de Noronha was discovered in 1503 by Vespucci and was occupied by several different countries, such as the Netherlands, France, Portugal and the United States; in 1942, it became Brazilian federal territory, and in 1988, it started to be administered by the Brazilian State of Pernambuco $[40,42]$. Currently, only the main island is occupied, and the entire terrestrial area is occupied by two federal protected areas: a Marine National Park, which is an IUCN category II protected area covering $70 \%$ of the terrestrial territory, and a Protected Area designated as IUCN category V that is destined for human use, covering $30 \%$ of the terrestrial area. The estimated human population was 2.9 thousand inhabitants in 2017, with approximately 7.5 thousand concurrent tourists visiting the archipelago at a given time in 2016 [43].

\section{Study design}

Five field campaigns were performed for 20 days each in February and November 2015, February, October and November 2016, and April 2018 to determine the density and distribution of the Noronha skink in different landscapes of the archipelago. This approach assumed no fluctuation of its density and distribution throughout the year. 
Two methods were used to assess the selected parameters, the first involving visual capture and recaptures of $T$. atlantica in different parcels conveniently located on the main island and the second involving point transects randomly distributed in accessible areas of the main island and some secondary islands and generating point abundance values. Both methods were performed simultaneously in all campaigns but at different sampling sites. The archipelago was stratified into different landscape types according to phytophysiognomy and anthropic pressure in seven categories: forest, shrub, beach, grassland, quarry, rocky coast, and urbanized.

The study was approved by the Ethics Committee of the School of Veterinary Medicine of the University of Sao Paulo (CEUA protocol number 1827250515) and by the Brazilian Ministry of Environment (SISBio permit number 41682).

\section{Visual capture and recapture}

The visual capture and recapture method was used in six parcels conveniently defined according to the accessibility of sampling sites on the main island of the archipelago of Fernando de Noronha. The parcels had a mean area of $31.3 \mathrm{~m}^{2}$ and were located in four of the seven landscape types of the main island. Each parcel was observed once daily for six subsequent days during the same campaign and were not resampled in a different campaign.

The animals observed inside the parcels were captured using a stick with a loop made of fishing line at the tip. Fishing line was chosen since can be slipped more easily than sewing thread. After capture, the animals were identified with non-permanent marks. Numeric marks were made on the back of the individuals with a water-based ink pen and remained on the animals for approximately two weeks. Captured animals were carefully inspected for ecdysis, avoiding those animals on which the marks would not remain long enough to complete the capture and recapture session. Marks were made only on the first day of the campaign, and marked and unmarked animals were counted. After the marking procedures, the animals were released inside the parcel.

The analysis was performed with Mark software [44] using the Poisson log-normal model [45], considering the population as closed (no births, deaths, emigration or immigration during the observations) and without using covariates. Of the seven previously categorized phytophysiognomy strata, four (quarry, shrub, urbanized and tree) were compared, and the observations were made within six days after the catches and marking (Supplementary Material).

\section{Point abundance}

The point abundance was determined as a complementary method to the visual capture and recapture approach. The data were obtained on the main island and secondary islands (Rata, Meio, Morro da Viúva, and Chapéu). 
The point transects were randomly distributed in the accessible areas of the archipelago. A single observer remained still for seven minutes, observing a $2 \mathrm{~m}$ radius area covering $12.6 \mathrm{~m}^{2}$ at each point. The observations were performed in the seven landscape types, which were sampled during the day when the temperature was approximately $29.8 \pm 2.2^{\circ} \mathrm{C}$, during the period of increased activity for the species defined by Rocha et al. [12]. These inclusion criteria are essential for the observation of ectothermic animals, which are more active in warm periods of the day.

The irregular spatial distribution of the abundance points was used to calculate the continuous variation of density using point interpolation analysis. The inverse distance weighting (IDW) method of the Interpolation plugin of QGIS software was used. The resulting raster had a grid size of $3.5 \times 3.5 \mathrm{~m}$, resulting in an area similar to the sampled area $\left(12.6 \mathrm{~m}^{2}\right)$. In each grid cell, the $T$. atlantica density was calculated by dividing the number of counted individuals by this area. The tridimensional area of the archipelago was used in the calculations of density and abundance. The digital elevation model and the calculations of the tridimensional area are described elsewhere [23].

\section{Morphometric evaluation}

To perform morphometric evaluation of $T$. atlantica, individuals were captured at aleatory points on the main and secondary (Rata, Meio, Sao Jose, and Chapeu) islands at distinct points from those used under the density and distribution assessment methods. Samples were obtained from the different landscape types of the archipelago.

The evaluated parameters were head length $(H L)$, rostrum-cloacal length (RCL), tail length $(T L)$, and total length (TotalL) measured with a rigid ruler (in centimetres) and body mass (in grams) measured with a digital scale with a one-gram precision. Autotomized animals and those with regenerating tails were not considered in the TL, TotalL or body mass analyses.

The morphometric parameters of the individuals were compared between the main and secondary islands and by sex. For this purpose, independent $t$-tests were used to compare the mean parameters. The variances of the parameters were checked by the Levene test.

\section{Declarations}

\section{Ethics approval and consent to participate}

Noronha skink sampling was approved by the Brazilian Ministry of Environment (SISBio permit number 41682) and the Ethics Committee of School of Veterinary Medicine of the University of Sao Paulo (CEUA protocol number 1827250515). 
Not applicable.

\section{Availability of data and materials}

The data that support the findings of this study are available from the corresponding author upon reasonable request.

Competing interests

The authors declare that they have no competing interests.

\section{Funding}

This study was funded by the Fundação de Amparo à Pesquisa do Estado de São Paulo (FAPESP) (process number 2016/16433-1), Rufford Foundation (RSG reference 18890-1).

This study was financed in part by the Coordenação de Aperfeiçoamento de Pessoal de Nível Superior Brasil (CAPES) - Finance Code 001.

\section{Authors' contributions}

All authors collected data, RAD and TM performed statistical analysis, all authors wrote the manuscript. RAD led the project. All authors read and approved the final manuscript.

\section{Acknowledgements}

To Instituto Chico Mendes de Conservação da Biodiversidade (ICMBio) for logistical support and Fire Department of Fernando de Noronha for providing the transport to the secondary islands of the archipelago.

\section{References}

1. Wilson EO, MacArthur RH.The theory of island biogeography. Princeton University Press, Princeton $\mathrm{NJ} ; 1967$.

2. MacArthur RH, Diamond JM, Karr JR. Density compensation in island faunas. Ecology. 1972; 53(2): 330-342.

3. Kier G, Kreft H, Lee TM, Jetz W, Ibisch PL, Nowicki C, Mutke J, Barthlott W. A global assessment of endemism and species richness across island and mainland regions. P Natl Acad Sci USA. 2009; 106(23): 9322-9327.

4. Whittaker RJ, Fernández-Palacios JM. Island biogeography: ecology, evolution, and conservation. 2 ed. Oxford University Press, Oxford; 2007.

5. Triantis KA,Borges PA, Ladle RJ, Hortal J, Gaspar C, Dinis F, mendonça E, Silveira LMA, Gabriel R, Melo C, Santos AMC, Amorim IR, Ribeiro SP, Serrano ARM, Quartau JA, Whittaker RJ. Extinction debt 
on oceanic islands. Ecography. 2010; 33(2): 285-294.

6. McKinney ML. Urbanization, biodiversity, and conservation: the impacts of urbanization on native species are poorly studied, but educating a highly urbanized human population about these impacts can greatly improve species conservation in all ecosystems. BioScience. 2002; 52(10): 883-890.

7. Galli A, Wackernagel M, Iha K, Lazarus E. Ecological footprint: implications for biodiversity. Biol Conserv. 2014. 173: 121-132.

8. Sinervo B, Méndez-de-la-Cruz F, Miles DB, Heulin B, Bastiaans E, Cruz MVS, Lara-Resendiz R, Martínez-Méndez N, Calderón-Espinosa ML, Meza-Lázaro RN, Gadsen H, Avila LJ, Morando M, De la Riva IJ, Sepulveda PV, Rocha CFD, Ibargüengoytía N, Puntriano CA, Massot M, Lepetz V, Oksanen TA, Chapple DG, Bauer AM, Branch WR, Colbert J, Sites Jr JW. Erosion of lizard diversity by climate change and altered thermal niches. Science. 2010; 328(5980): 894-899.

9. Carleton MD, Olson SL. Amerigo Vespucci and the rat of Fernando de Noronha: a new genus and species of Rodentia (Muridae: Sigmodontinae) from a volcanic island off Brazil's continental shelf. Am Mus Novit. 1999; 3256: 1-59.

10. Agência Estadual de Meio Ambiente. Lista Estadual de Répteis Ameaçados - Pernambuco, Governo do Estado de Pernambuco. 2017. http://www.cprh.pe.gov.br/home/42872;57450;10;3351;17946.asp. Accessed 10 Dec 2017.

11. Pereira AG, Schrago CG. Arrival and diversification of mabuyine skinks (Squamata: Scincidae) in the Neotropics based on a fossil-calibrated timetree. PeerJ. 2017; 5: e3194.

12. Rocha CFD, Vrcibradic, Menezes VA, Ariani CV. Ecology and natural history of the easternmost native lizard species in South America, Trachylepis atlantica (Scincidae), from the Fernando de Noronha archipelago, Brazil, J Herpetol. 2009; 43(3): 450-459.

13. Sazima I, Sazima C, Sazima M. Little dragons prefer flowers to maidens: a lizard that laps nectar and pollinates trees. Biota Neotrop. 2005; 5: 185-192.

14. Souza ACA. Phylogeography, ecology and conservation of skink adamastor, Trachylepis adamastor. Dissertation, Universidade de Évora. 2017.

15. Gerlach J. Population and conservation status of the reptiles of the Seychelles islands', Phelsuma. 2008; 16: 31-48.

16. Rocamora G. Eradication of invasive animals and other island restoration practices in Seychelles: achievements, challenges and scaling up perspectives. In: Veitch CR, Clout MN, Martin AR, Russell JC, West CJ (eds). Island invasives: scaling up to meet the challenge. IUCN, Gland, Switzerland; 2019. p. 588.

17. Novosolov M, Rodda GH, Feldman A, Kadison AE, Dor R, Meiri S. Power in numbers. Drivers of high population density in insular lizards. Global Ecol Biogeogr. 2016; 25(1): 87-95.

18. Buckley LB, Jetz W. Insularity and the determinants of lizard population density. Ecol Lett. 2007; 10(6): 481-489.

19. Abrahão CR, Russell JC, Silva JCR, Ferreira F, Dias RA. Population assessment of a novel island invasive: tegu (Salvator merianae) of Fernando de Noronha. In: Veitch CR, Clout MN, Martin AR, 
Russell JC, West CJ (eds). Island invasives: scaling up to meet the challenge. IUCN, Gland, Switzerland; 2019. p. 317-325.

20. Chiarello AG, Srbek-Araujo A, Del-Duque Jr H, Coelho E, Rocha C. Abundance of tegu lizards (Tupinambis merianae) in a remnant of the Brazilian Atlantic forest. Amphibia-Reptilia. 2010; 31(4): 563-570.

21. Adler GH, Levins R. The island syndrome in rodent populations. Q Rev Biol. 1994; 69(4): 473-490.

22. Serafini TZ, França GB, Andriguetto-Filho JM. Brazilian oceanic islands: known biodiversity and its relation to the history of human use and occupation. J Integr Coast Zone Manag. 2010; 10(3): 281301.

23. Dias RA, Abrahão CR, Micheletti T, Mangini PR, Gasparotto VPO, Pena HFJ, Ferreira F, Russell JC, Silva JCR. Prospects for domestic and feral cat management on an inhabited tropical island. Biol Invasions. 2017; 19(8): 2339-2353.

24. Medina FM, Bonnaud E, Vidal E, Tershy BR, Zavaleta ES, Donlan CJ, Keith BS, Le Corre M, Horwath SV, Nogales M. A global review of the impacts of invasive cats on island endangered vertebrates. Global Change Biol. 2011; 17(11): 3503-3510.

25. Nogales, M. Vidal E, Medina FM, Bonnaud E, Tershy BR, Campbell KJ, Zavaleta ES. Feral cats and biodiversity conservation: the urgent prioritization of island management. BioScience. 2013; 63(10): 804-810.

26. Case TJ, Bolger DT. The role of introduced species in shaping the distribution and abundance of island reptiles. Evol Ecol. 1991; 5(3): 272-290.

27. Smith MJ, Cogger H, Tiernan B, Maple D, Boland C, Napier F, Detto T, Smith P. An oceanic island reptile community under threat: the decline of reptiles on Christmas Island, Indian Ocean. Herpetol Conserv Bio. 2012; 7(2): 206-218.

28. Gaiotto, JV. Influência do transporte de matéria marinha por aves sobre teias tróficas insulares. Dissertation, Universidade Federal do Rio Grande; 2018.

29. Russell JC. Abrahão CR, Silva JCR, Dias RA. Management of cats and rodents on inhabited islands: An overview and case study of Fernando de Noronha , Brazil. Persp Ecol Conserv. 2018; 16(4): 193200.

30. Goss RJ. Aging versus growth. Perspect Biol Med. 1974; 17(4): 485-494.

31. Andrews RM. Patterns of growth in reptiles. In: Gans DC, Pugh FH (eds.). Biology of the Reptilia. Physiology, New York, pp. 273-320; 1982.

32. Olsson $M$, Shine R. Does reproductive success increase with age or with size in species with indeterminate growth? A case study using sand lizards (Lacerta agilis). Oecologia. 1996; 105: 175178.

33. Millien V, Damuth J. Climate change and size evolution in an island rodent species: new perspectives on the island rule. Evolution. 2004; 58(6): 1353-1360. 
34. Norrdahl K, Heinilä H, Klemola T, Korpimäki E. Predator-induced changes in population structure and individual quality of Microtus voles: a large-scale field experiment. Oikos. 2004; 105(2): 312-324.

35. Lomolino MV. Body size evolution in insular vertebrates: generality of the island rule. J Biogeogr. 2005; 32(10): 1683-1699.

36. Russell JC, Ringler D, Trombini A, Le Corre M. The island syndrome and population dynamics of introduced rats. Oecologia. 2011; 167(3): 667-676.

37. Nunes MFC, Barbosa-Filho RC, Roos AL, Mestre LAM. The cattle egret (Bubulcus ibis) on Fernando de Noronha archipelago: history and population trends. Rev Bras Ornitol. 2010; 18(4): 315-327.

38. Silva-Jr JM, Péres-Jr AK, Sazima I. Euprepis atlanticus (Noronha skink) predation. Herpetol Rev. 2005; 36: 62-63.

39. De Almeida FFM. Geologia e petrologia do arquipélago de Fernando de Noronha. Serviço Gráfico do Instituto Brasileiro de Geografia e Estatística, Brasília; 1955.

40. Teixeira W, Cordani UG, Menor EA, Teixeira MG, Linsker R (ed.). Arquipélago de Fernando de Noronha. O paraíso do vulcão. Terra Virgem Editora, São Paulo; 2003.

41. Marques FA, Ribeiro MR, Bittar SMB, Tavares Filho AN, Lima JFWF. Caracterização e classificação de neossolos da ilha de Fernando de Noronha (PE). Rev Bras Cienc Solo. 2007; 31(6): 1553-1562.

42. Ministério do Meio Ambiente [MMA]. Parque Nacional Marinho de Fernando de Noronha - Cadastro Nacional de Unidades de Conservação. MMA, Brasília; 2019.

http://sistemas.mma.gov.br/cnuc/index.php?

ido=relatorioparametrizado.exibeRelatorio\&relatorioPadrao=true\&idUc=186. Accessed 8 Mar 2019.

43. Instituto Brasileiro de Geografia e Estatística [IBGE]. História de Fernando de Noronha Pernambuco PE, Instituto Brasileiro de Geografia e Estatística; 2017. https://cidades.ibge.gov.br/brasil/pe/fernando-de-noronha/historico. Accessed 10 Jul 2019.

44. Burnham KP, White GC. Program MARK: survival estimation from populations of marked animals. J Bird Stud. 1999; 46(1): S120-S139.

45. McClintock BT, White GC, Antolin MF, Tripp DW. Estimating abundance using mark - resight when sampling is with replacement or the number of marked individuals is unknown. Biometrics. 2009; 65(1): 237-246.

\section{Figures}

\section{Figure 1}

Noronha skink (Trachylepis atlantica) (photography by Vinicius Gasparotto). 


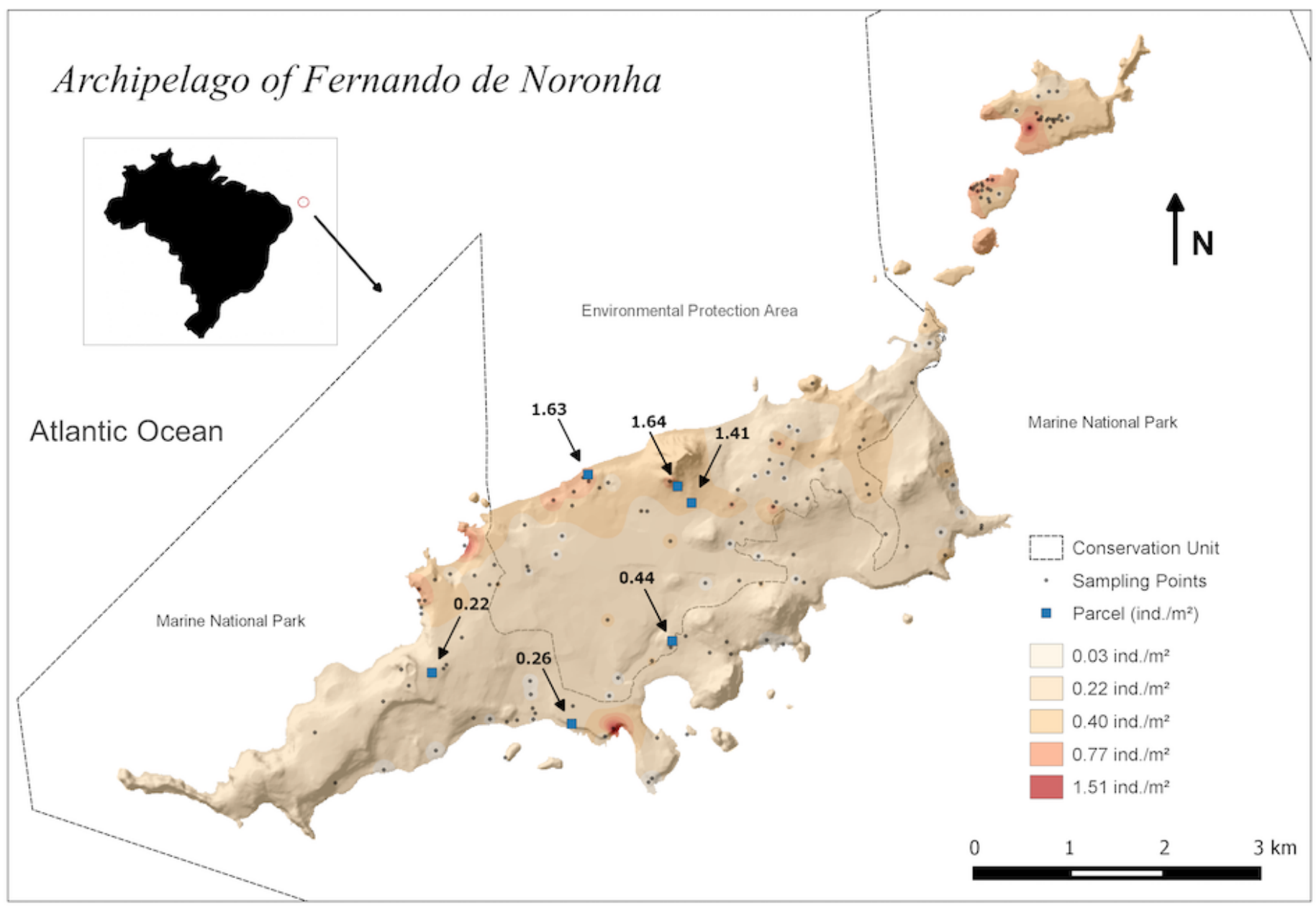

Figure 2

Density of the Noronha skink (Trachylepis atlantica) on the Fernando de Noronha archipelago, sampling points, and parcels' locations where capture and visual recapture were performed.

\section{Supplementary Files}

This is a list of supplementary files associated with this preprint. Click to download.

- supplementarymaterial.pdf 